\title{
Inhibitory Potential of Acephate and Ethanol Extract of Bacopa Monnieri on AChE in Rat Cortex and Hippocampus
}

\author{
Manju Tembhre*, Shanta Ahirwar, Sandhya Gour, Anjali Namdeo \\ M K Ponda College of Business and Management, Bhopal- 462038, India and Gov. M V M Science College \\ Bhopal-462003, India. \\ * Corresponding author. Tel.: +91-755-2779005/2854711/22/33; email: m_tembhre@yahoo.co.in. \\ Manuscript submitted July 24, 2014; accepted September 20, 2014. \\ doi: 10.17706/ijbbb.2015.5.1.45-53
}

\begin{abstract}
The objective of present study was to evaluate the in vivo effect of Bacopa monnieri leaf extract $(100 \mathrm{mg} / \mathrm{kg})$ and acephate $(37.8 \mathrm{mg} / \mathrm{kg})$ on Acetylcholinesterase (AChE) activity, kinetics and histology of cerebral cortex and hippocampus of brain of male albino rat. AChE activity was measured spectrophotometrically according to the method of Ellman et al. The acephate inhibited AChE activity strongly in cerebral cortex (72.5\%; $P<0.02$ ) than in hippocampus $(55.6 \%$; $P<0.02)$. Bacopa monnieri similarly elicited higher AChE inhibition in cerebral cortex (51.6\%; $P<0.05)$ than in hippocampus (38\%; $P$ $<0.01$ ). However, synergistic inhibitory effect was recorded in rats pretreated with Bacopa monnieri followed by acephate exposure. Kinetic study of treated groups demonstrated competitive AChE inhibition in the brain regions, which was evident by increased $K_{\mathrm{m}}$ and unchanged $V_{\max }$ values against the control group. The histopathological examinations showed degeneration of pyramidal cells, deformity of neurocytes and vacuole formation in cytoplasm. These changes were pronounced with acephate. Our result shows that Bacopa monnieri has anti-cholinesterase potential hence it could provide novel pharmacological leads of potential benefit to the treatment of Alzheimer's disease and therefore warrant further investigation.
\end{abstract}

Keywords: AChE, acephate, Bacopa monnieri, cerebral cortex, hippocampus.

\section{Introduction}

The levels of acetylcholine and acetylcholinesterase play very important role in the proper function of the nervous system. It's imbalance in the neurons and synaptic junction leads to a number of neural diseases, particularly Alzheimer's disease (AD), Myasthenia gravis (MG), and anti-cholinesterase poisoning. It has been proved that cholinesterase inhibitors boost the signal transmission in nerve synapses by prolonging acetylcholine and are useful for curing CNS degenerative diseases [1]. Some AChE inhibitors like galantamine and donezepil are presently in practice to treat AD patients, but they exhibit moderate side effects. Nature is a rich source of biological and chemical diversity. The history of drug discovery shows that plants are highly rich sources in the search for new active compounds [2]. Many synthetic drugs owe their origin to the plant-based complementary medicine. Since Alzheimer's disease is one of the most common causes of death worldwide, new treatment strategies based on medicinal plants have been focused. Recently many medicinal plants have been screened to know for their anti-cholinesterse property [3]. The extracts prepared from cinnamon [Cinnamomum cassia Presl (Lauraceae) [4], Iris suaveolens [5], Ficus carica [6], Tutin, (Umbelliferae), [7] and Datura stramonium [8] have shown anticholoinestrase potential. Alzheimer's 
disease is associated with impairment in cholinergic transmission. A number of AChE inhibitors have been considered as candidates for the treatment of Alzheimer's disease as the most useful strategy [9], [10]. In this disease there is deficit of acetylcholine which causes a progressive degenerative neurologic disorder resulting in impaired memory and behavior. Currently, reversible inhibitors of AChE are used in treatment of Alzheimer's disease [11]. The alkaloids are the major compounds isolated from various species of plants showing inhibitory activity for AChE. Therefore, the present study was undertaken to explore the comparative effect of action of acephate and Bacopa monnieri in search of promising treatment for Alzheimer's disease.

\section{Materials and Methods}

\subsection{Preparation of Extract}

Fresh Bacopa monnieri were procured from Jawaharlal Nehru Agricultural University, Jabalpur (M.P.) India. Leaves and twigs were thoroughly washed in water; shade dried and was ground to powder. Ethanol extract of Bacopa monnieri was prepared using Soxhlet apparatus. Filtrate was frozen, freeze-dried and re-constituted in de-ionized water prior to assy.

\subsection{Animals and Treatment}

20 male albino rats of $125-150 \mathrm{~g}$ were housed separately in polypropylene cages, under controlled laboratory condition at $30^{\circ} \mathrm{C}$ with $12 / 12$ hours light and dark cycle for 15 days. They were allowed free access to commercial feed and water ad libitum. The animals were grouped in five and treated orally as: Group-I : Ground nut oil $1 \mathrm{ml} / \mathrm{kg}$, served as control (vehicle); Group-II: $37.8 \mathrm{mg} / \mathrm{kg}$ acephate $11 / 25^{\text {th }}$ of $L D_{50}$ ) in ground nut oil daily for 4 days; Group-III : Ethanol extract of Bacopa monneiri $100 \mathrm{mg} / \mathrm{kg}$ in deionized water for 7 days; Group-IV: Pretreatment of ethanol extract of Bacopa monneri (100mg/1kg) for 7 days daily followed by $37.8 \mathrm{mg} / \mathrm{kg}$ acephate for 4 days.

\subsection{Tissue Preparation}

Animals were euthanized by decapitation and brains were dissected out according to Zeman and Innes [12]. Cerebral cortex and Hippocampus were rapidly removed, weighed and thoroughly washed with isotonic saline. Tissues were homogenized in buffer followed by centrifugation at $4^{\circ} \mathrm{C}$ and supernatant was used as the source of enzyme.

\subsection{Determination of AChE Activity}

AChE activity was measured spectrophotometrically according to Ellman et al. [13] in the Brain regions. Homogenates were diluted with $2.6 \mathrm{ml} \mathrm{0.1}$ M Sodium phosphate buffer (pH 7.4) to which $100 \mathrm{mM}$ DTNB and $75 \mathrm{mM}$ ATChI was added. The rate of color production was measured at $412 \mathrm{~nm}$ in SL $164 \mathrm{UV}$-VIS spectrophotometer. All measurements were done in duplicate. Specific activity was expressed in $\mu$ $\mathrm{mol} / \mathrm{min} / \mathrm{mg}$ protein.

\subsection{Protein Estimation}

Protein was estimated following the method of Lowry et al. [14] using BSA as the standard. Samples of homogenate were diluted with reagents then $0.5 \mathrm{ml}$ Folin's reagent was added, and after $20 \mathrm{~min}$ read at 620 $\mathrm{nm}$ against a reagent blank. Measurements were done in duplicate.

\subsection{AChE Kinetics}

Lineweaver-Burk plots were drawn from assays using acephate $(37.8 \mathrm{mg} / \mathrm{kg})$ and Bacopa monneiri extract $(100 \mathrm{mg} / \mathrm{kg})$ at various substrate concentrations $(0.66 \mathrm{mM}, 0.44 \mathrm{mM}, 0.33 \mathrm{mM}, 0.26 \mathrm{mM} \mathrm{ATCI})$. From these kinetic parameters $\left(K_{\mathrm{m}} \& V_{\max }\right)$ were determined for each assay by plotting the reciprocals of 
velocity and substrate concentrations.

\subsection{Histological Examination}

Tissues from each group of rats were fixed in aqueous Bouin's fluid, dehydrated and embedded in paraffin wax. Serial sections were cut at 7 micron and stained with Haematoxylin and Eosin. The sections were microphotographed at $100 \times$ and $400 \times$ with computer-aided microscope(Leica).

\subsection{Statistical Analysis}

For the data of statistical comparison between different treatments and control, data were analyzed by student's t-test to determine the effect of the treatment. The level for the accepted statistical significance was $P>0.05$.

\section{Results}

\subsection{AChE Inhibition}

As shown in Table 1, the AChE activity in control rat was higher in the hippocampus $(1.81 \pm 0.54)$ than in the cerebral cortex $(1.35 \pm 0.51)$. The acephate produced higher AChE inhibition in the cerebral cortex $(72.5 \%)$ as compared to hippocampus (55.6\%). Ethanol extract of Bacopa monnieri demonstrated $51.6 \%$ AChE inhibition in the cerebral cortex while it was $38.1 \%$ in the hippocampus. However, combined group showed synergistic AChE inhibition in the cerebral cortex (83.5 \%) and hippocampus (83.7 \%).

Table 1. Effect of Acephate (37.8 mg/kg), Bacopa monnieri $(100 \mathrm{mg} / \mathrm{kg})$ and Pretreatment of Bacopa monnieri $(100 \mathrm{mg} / \mathrm{kg})$ Followed by acephate $(37.8 \mathrm{mg} / \mathrm{kg})$ on AChE of Brain Regions of Rat.

\begin{tabular}{ccccc}
\hline \hline & & \multicolumn{3}{c}{ Treated Groups } \\
\cline { 3 - 5 } Tissue & Control Group & Acephate & $\begin{array}{c}\text { Bacopa } \\
\text { monnieri }\end{array}$ & $\begin{array}{c}\text { Bacopa monnieri } \\
\text { and Acephate }\end{array}$ \\
\hline Cerebral cortex & $1.35 \pm 0.51$ & $\begin{array}{c}0.37 \pm 0.22^{* *} \\
(-72.5)\end{array}$ & $\begin{array}{c}0.65 \pm 0.5^{* * *} \\
(-51.6)\end{array}$ & $\begin{array}{c}0.22 \pm 0.08^{*} \\
(-83.5)\end{array}$ \\
Hippocampus & - & & & $0.29 \pm 0.04$ \\
& $1.81 \pm 0.54$ & $0.80 \pm 0.56^{* * *}$ & $1.12 \pm 0.52^{*}$ & $(-83.7)$ \\
\hline
\end{tabular}

The AChE specific activity is Expressed in $\mu$ moles of ACTI hydrolyzed / mg protein /min. Each value is mean \pm S.D. of 5 individual observations. $P<0.01^{*} ; P<0.02^{* *} ; P<0.05^{* * *}$. AChE \% inhibition given in parenthesis.

Table 2. Effect of Acephate $(37.8 \mathrm{mg} / \mathrm{kg})$, Bacopa monnieri $(100 \mathrm{mg} / \mathrm{kg})$ and Pretreatment of Bacopa monnieri $(100 \mathrm{mg} / \mathrm{kg})$ Followed by Acephate $(37.8 \mathrm{mg} / \mathrm{kg})$ on AChE Kinetics of Brain Regions of Rat

\begin{tabular}{|c|c|c|c|c|c|}
\hline \multirow[b]{2}{*}{ Tissue } & \multirow[b]{2}{*}{ Control } & \multicolumn{3}{|c|}{$K_{\mathrm{m}} \times 10^{-3} \mathrm{M}$ of Treated groups } & \multirow[b]{2}{*}{$V_{\max }$} \\
\hline & & Acephate & $\begin{array}{l}\text { Bacopa } \\
\text { monnieri }\end{array}$ & $\begin{array}{l}\text { Bacopa monnieri } \\
\text { and Acephate }\end{array}$ & \\
\hline Cerebral cortex & $1 \pm 0.5$ & $\begin{array}{l}1.60 \pm 0.8^{* *} \\
(+60 \%)\end{array}$ & $\begin{array}{l}1.11 \pm 0.54^{* *} \\
(+11 \%)\end{array}$ & $\begin{array}{l}1.80 \pm 0.54^{*} \\
(+80 \%)\end{array}$ & 0.4 \\
\hline Hippocampus & $0.67 \pm 0.61$ & $\begin{array}{l}0.84 \pm 0.50^{*} \\
(+25 \%)\end{array}$ & $\begin{array}{l}0.76 \pm 0.62^{* * *} \\
(+13 \%)\end{array}$ & $\begin{array}{l}1.25 \pm 0.52^{*} \\
(+86 \%)\end{array}$ & 0.25 \\
\hline
\end{tabular}

Each value is mean \pm S.D. of 5 individual observations. $P<0.01^{*} ; P<0.02^{* *} ; P<0.05^{* * *}$. (Per cent elevation in $K_{\mathrm{m}}$ values given in parenthesis.) 


\subsection{AChE Inhibitory Kinetics}

AChE inhibition kinetics of acephat, Bocopa monnieri ethanol extract and combined treatment were determined from Lineweaver-Burk plots (Fig. 1). The $K_{\mathrm{m}}$ and $V_{\max }$ values were derived from the trend line equation of the graphs (Table 2). The acephat and Bocopa monnieri both showed competitive AChE inhibition. This is evident from the series of lines crossing the $y(1 / v)$ axis at the same point - i.e. $V_{\max }$ is unchanged, but with a decreasing value of $1 / K_{\mathrm{m}}$ (and hence a higher $K_{\mathrm{m}}$ ) in the presence of the inhibitor. The result as shown in Table 2 revealed that ethanol extract of Bocopa monnieri followed by oral dose of acephate to rats, caused remarkable increase in $K_{\mathrm{m}}$ in cerebral cortex and hippocampus.
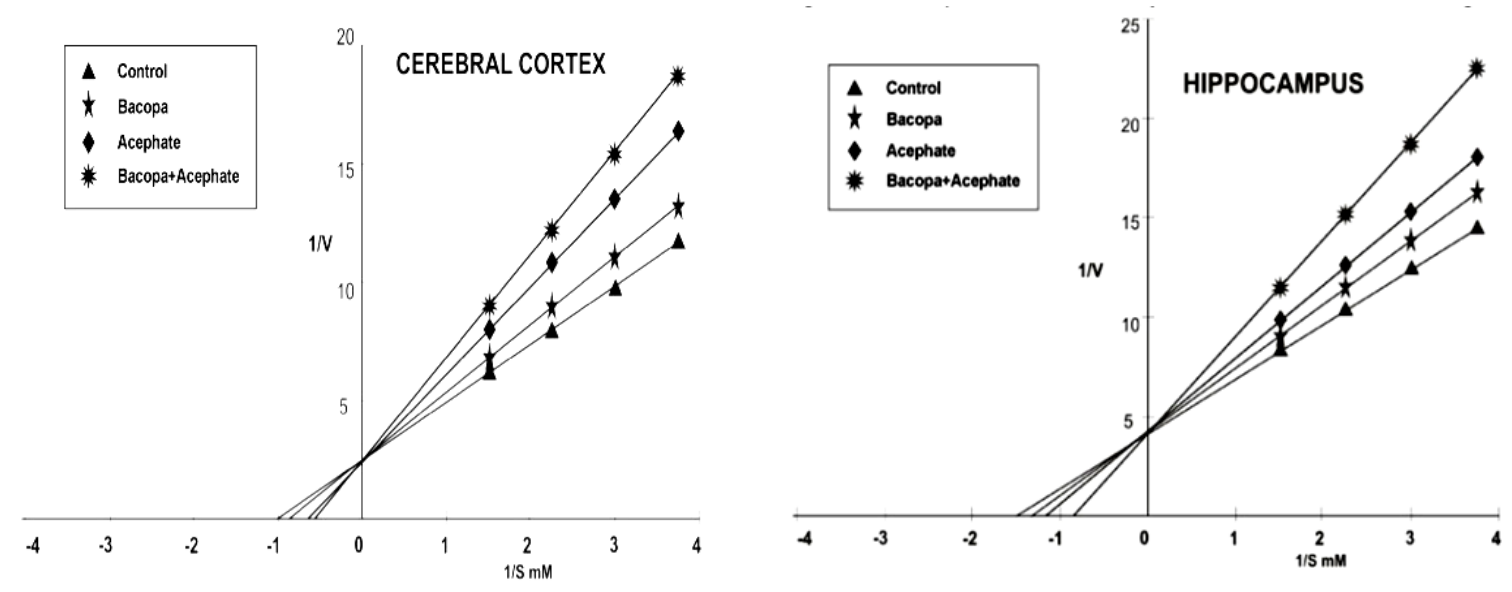

Fig. 1. Line Weaver-Burk plot of in vivo inhibition of AChE by acephate (37.8 mg/kg ), Bacopa monnieri (100 $\mathrm{mg} / \mathrm{kg})$ and pretreatment of Bacopa monnieri $(100 \mathrm{mg} / \mathrm{kg})$ followed by acephate $(37.8 \mathrm{mg} / \mathrm{kg})$ treatment in cerebral cortex and hippocampus of rat brain. $\mathrm{S}$ is the concentration of ATCI, each point is mean of five assays.

\subsection{Histopathology}

Exposure of acephate $(37.8 \mathrm{mg} / \mathrm{kg}$ ), ethanol extract of Bacopa monnieri $(100 \mathrm{mg} / \mathrm{kg})$, pretreatment of ethanol extract of Bacopa monnieri $(100 \mathrm{mg} / \mathrm{kg}$ ) for seven days followed exposure of acephate $(37.8 \mathrm{mg} / \mathrm{kg})$ for four days caused histological alterations in the Brain regions of rats.

Pyknosis and degeneration of pyramidal cells were observed in the cerebral cortex due to acephate (Fig. 2). We also noticed gradual concentrations of neurocytes. However, Bocopa monnieri showed deformity in the pyramidal cells and neurocytes in cerebral cortex. The changes were prominent in the cerebral cortex with the formation of vacuoles in rats treated with Bacopa followed by acephate.

The histopathological changes in the hippocampus of rat brain (Fig. 3) exposed to acephate, Bocopa monnieri and pre-treated with Bocopa monnieri followed by acephate indicated bifocal concentration of cytoplasm of CA1 layer and pyknosis in pyramidal cells in CA1 layer. These changes were not clearly seen in the hippocampus with treatment of Bocopa monnieri.

\section{Discussion}

A number of experimental studies have indicated that OP pesticides inhibit AChE activity in various organisms and they show different sensitivity to these pesticides [15]-[18]. The present study demonstrates significant inhibition in AChE in both the brain regions of rat exposed to $37.8 \mathrm{mg} / \mathrm{kg}$ acephate (Table 1). The inhibition was higher in the cortex than in hippocampus. Progressive inhibition of brain AChE activity 
of rat with various pesticides was reported [19]-[22]. Swamy et al. [23] found higher AChE inhibition initially in the cortex and later in the striatum due to Monocrotophos. Similar observations were reported with Dichlorvos [24]. Malathion also elicits higher AChE inhibition in the striatum [25].

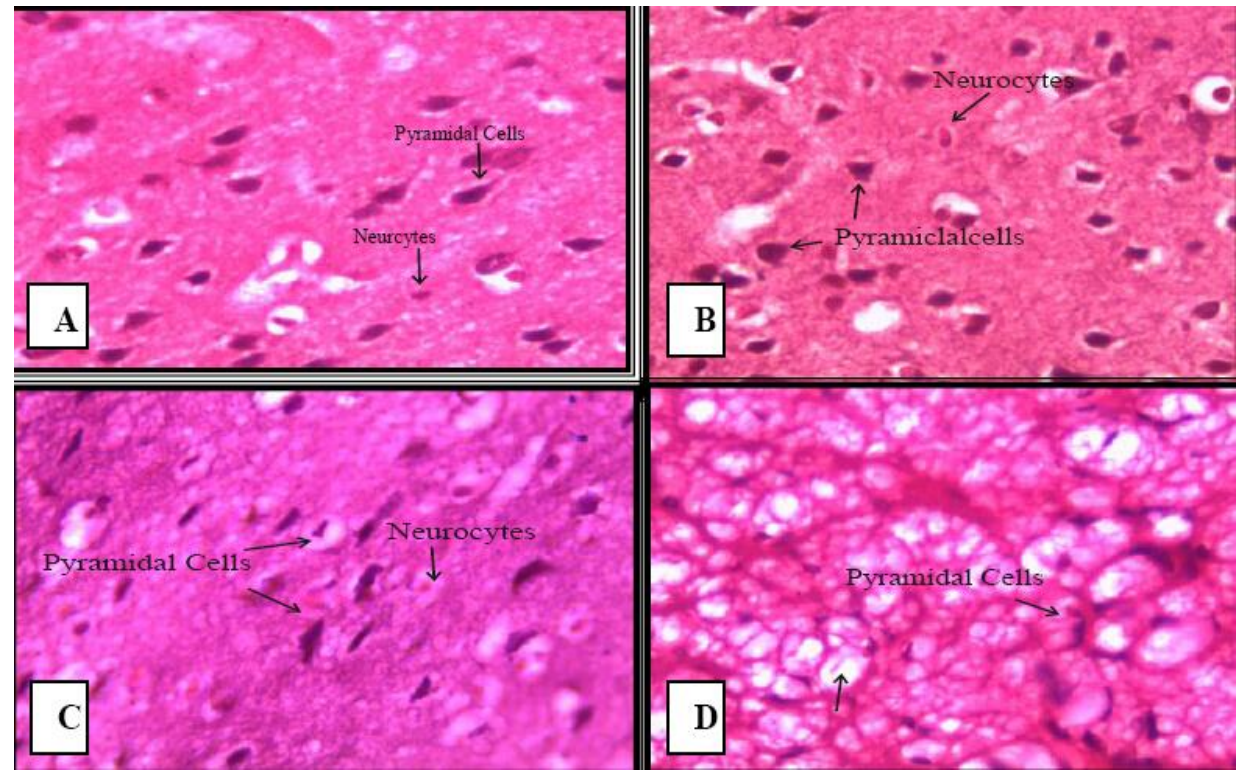

Fig. 2. Photomicrograph of T. S. of cerebral cortex of rat brain. (A) Control, showing the normal structure. (B) Acephate $(37.8 \mathrm{mg} / \mathrm{kg})$, showing degeneration of neurocytes and pyknosis in the pyramidal cell. (C) Bacopa monnieri $(100 \mathrm{mg} / \mathrm{kg})$, showing gradual concentration of neurocytes. (D) Pretreatment of Bcaopa monnieri (100 mg/kg.) followed by Acephate $(37.8 \mathrm{mg} / \mathrm{kg}$ ), showing vacuoles due to cytoplasm destruction. H.E. × 400.

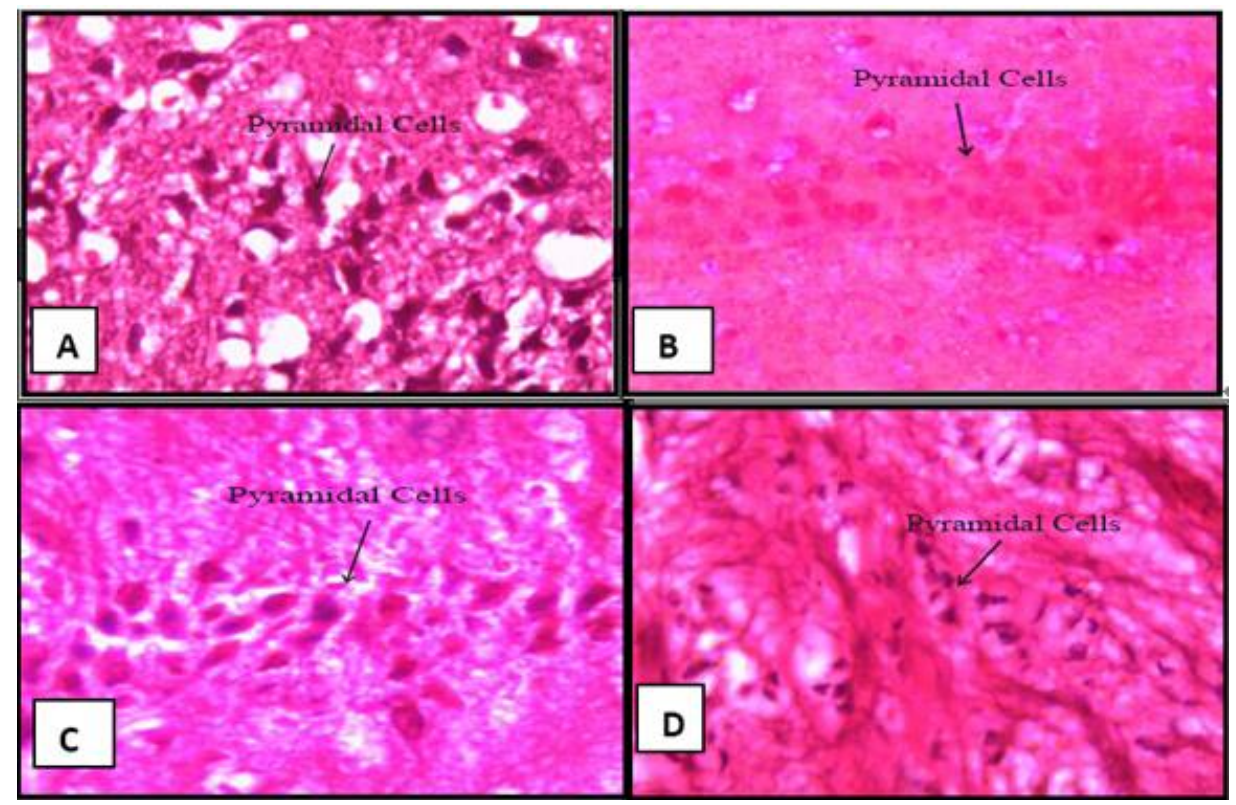

Fig. 3. Photomicrographs of T S of hippocampus of Rat brain; (A) Control, showing the normal structure. (B) Exposed to Acephate (37.8 mg/kg), showing pyknosis in pyramidal cells in CAI layer. (C) Exposed to Bacopa monnieri $(100 \mathrm{mg} / \mathrm{kg}$ ), shows no clear changes. (D) Exposed to pretreatment of Bacopa monnieri (100 $\mathrm{mg} / \mathrm{kg}$ ) followed by acephate $(37.8 \mathrm{mg} / \mathrm{kg})$ showing pyknosis in pyramidal cells in CAI layer. H. E. $\times 400$.

We prepared Bacopa monnieri extract in ethanol as we got high yield of bacoside, this was also earlier 
confirmed by Das et al. [26] and Chandel et al. [27]. Different species of Narcissus has been recently investigated and for the first time reported for the co-relation of plants alkaloids and AChE inhibition [9]. This presents a new approach drug about discovery. Previously, 26 species of Narcissus were found having many-fold AChE inhibitory potential [11]. Anticholinesterase property of extract containing heptyl-physotigmine was studied by De Sarno et al. [28]. $5 \mathrm{mg} / \mathrm{kg}$ extract produced $82 \%$ inhibition in AChE of whole brain of rat. However, AChE inhibition was $40 \%$ in cerebellum and $82 \%$ in frontal cortex and medial septum. AChE inhibitory potency of huperzine-B, chines moss in rat brain was reported by Liu et al. [29]. It has been demonstrated that huperzine-A, an alkaloid isolated from chines club moss, Huperzine serreta, was a reversible inhibitor of AChE. The dose of huperzine-A produces 54\% AChE inhibition and increases the acetylcholine level to 230 -time base line value. Hence they strongly recommended the huperzine-A promising compound for the pharmacological use in dementia [2]. The ethanol extract of cinnamon exhibited $63.02 \%$ AChE inhibition [4]. The petroleum ether extract of Iris suaveolens indicated moderate anticholinesterase activity [5]. It has been revealed that the n-hexane and acetone extracts of Ficus carica exerted a notable AChE inhibition [6]. Our study reveals anticholiesterase potential of Bacopa monnieri.

Our enzyme kinetic study of control group of rat showed the highest $K_{\mathrm{m}}$ value of Cerebral cortex $(1.0 \times$ $10^{-3} \mathrm{M}$ ). Inhibitory kinetic of AChE of brain regions was investigated by few workers' [30]. The in vivo inhibitory effect of acephate and Bacopa monnieri on the AChE kinetic of the brain regions rat has not been reported so far. The all treatments yield a competitive inhibition in AChE of cerebral cortex and hippocampus of rat.

Our histopathological study shows changes due to treatment of acephate. Gradual concentrations of neurocytes, pkynosis and degeneration of pyramidal cells in cerebral cortex and CA1 or CA3 layer in Hippocampus were observed with acephate. Changes were more pronounced in the cerebral cortex with the formation of vacuoles due to the aggregation of cytoplasm in rat pretreated with Bocopa monnieri followed by acephate. Kedar et al. [31] observed lesions with dose of sarin in the hippocampus, pyriform cortex and thalamus of rat. They further, observed significant decline in the area of CA1 and CA3 hippocampal cells. However, the damage was prominent in frontal cortex due to soman poising. Similar histopathological alterations due to soman were reported by various investigators [32]-[34]. We can conclude that this study indicates that the ethanol extract of Bacopa moneiri may be a new potential resource of natural anticholinesterase compounds. The results of this study indicate that there is a great potential to search for novel usage of this medicinal herbs for the treatment of AD.

\section{References}

[1] Heinrich, M., \& Teoh, H. L. (2004). Galantamine from snowdrop, the development of a modern drug against Alzheimer's disease from local Caucasian knowledge. Journal of Ethnopharmacol, 92(2-3), 147-162.

[2] Tonduli, L. S., Testylier, G., Masqueliez, C., Lallement, G., \& Monmaur, P. (2000). Effect of heperzine used as pre-treatment against soman -induced seizures. Neurotoxicology, (15), 1-9.

[3] Ingkaninan, K., Temkitthawon, P., Chuenchom, K., Yuyaem, T., \& Thongnoi, W. (2003). Screening for acetylcholinesterase inhibitory activity in plants used in Thai traditional rejuvenating and neurotonic remedies. Journal of Ethnopharmacology, 89(2-3), 261-264.

[4] Boğa, M., Hacıbekiroğlu, I., \& Kolak, U. (2011). Antioxidant and anticholinesterase activities of eleven edible plants. Pharm Biol., 49(3), 290-295.

[5] Hacibekiroğlu, I., \& Kolak, U. (2011). Antioxidant and anticholinesterase constituents from the petroleum Ether and chloroform extracts of Iris suaveolens. Phytotherapy Research, 25(4), 522-529. 
[6] Orhan, I. E., Ustün, O., \& Sener, B. (2011). Estimation of cholinesterase inhibitory and antioxidant effects of the leaf extracts of Anatolian Ficus carica var. domestica and their total phenol and flavonoid contents. Nat. Prod. Commun., 6(3), 375-875.

[7] Şenol, F. S., Yilmaz, G., Şener, B., Koyuncu, M., \& Orhan, I. (2010). Preliminary screening of acetylcholinesterase inhibitory and antioxidant activities of Anatolian Heptaptera species. Pharm. Biol., 48(3), 337-341.

[8] Namdeo, A., Tembhre, M., Banerjee, S., Gour, S., \& Ahirwar, S. (2013). Inhibitory efficacy of Chlorpyriphos and Datura stramonium on Acetylcholinesterase activity, kinetics and histology of brain of Catla catla. Asian Journal of Experimental Sciences, 27(1), 47-56.

[9] Rønsted, N., Savolainen, V., Mølgaard, P., \& Jäger, A. K. (2008). Phylogenetic selection of Narcissus species for drug discovery. Biochemical Systematics and Ecology, 36, 417-422.

[10] Ahirwar, S., Tembhre, M., Gour, S., \& Namdeo, A. (2012). Anticholinesterase efficacy of Bacopa monnieri against the brain regions of rat - a novel approach to therapy for Alzheimer's disease. Asian Journal of Experimental Sciences, 26(1), 65-70.

[11] López, S., Bastida, J., Viladomat, F., \& Codina, C. (2002). Acetylcholinesterase inhibitory activity of some Amaryllidaceae alkaloids and Narcissus extracts. Life Science, 1(21), 2521-2529.

[12] Zeman, W., \& Innes, J. R. M. (1963). Craigie's Neuroanatomy of the Rat. New York: Academic Press.

[13] Ellman, G. L., Courtney, K. D., Andres, V. Jr., \& Featherstone, R. M. (1961). A new and rapid colorimetric determination of acetylcholinesterase activity. Biochem. Pharmacology, 7, 88-95.

[14] Lowry, O. H., Rosebrough, N. J., Farr, A. L., \& Randall, R. J. (1951). Protein measurement with folin phenol reagent. J. Bol. Chem., 193, 265-275.

[15] Silver, A. (1974). The Biology of Cholinesterase. Amsterdam: North-Holland Publishing Company.

[16] Satyadevan, S., Kumar, S., \& Tembhre, M. (1993). Acetylcholinesterase activity and enzyme kinetics in the brain of common carp, Cyprinus carpio subjected to sub lethal exposure to dimethoate. Biosci. Biotech. Biochem., 57(9), 1566-1567.

[17] Tembhre, M., \& Kumar, S. (1994). Effect of acute and chronic exposure to sub-lethal dose of dimethoate in the gut of Cyprinus carpio. J. Ecotoxicol. Environ. Monit., 4(3), 205-210.

[18] Tembhre, M. \& Kumar, S. (1995). Effect of sub-lethal concentration of methylamine on AChE activity and enzyme kinetics of alimentary canal of Cyprinus carpio. Ind. J. Z. Spect., 6(2), 39-41.

[19] Lim, D. K., Sivam, S. P., Haskin, B., \& Ho, I. K. (1993). Inhibition and recovery of acetylcholinesterase (AChE), activity in the discrete regions of rat brain following single dose administration of soman, sarin and tabun. Pharmacologis, 25, 222.

[20] Chambers, J. E., \& Carr, R. L. (1993). Inhibition patterns of brain acetylcholinesterase and hepatic and Plasma aliesterases following exposures to three phosphorothionate insecticides and their oxons in rats. Fundamantal and Applied Toxicology, 21, 111-119.

[21] Tembhre, M., \& Kumar, S. (1997). Acetylcholinesterase inhibition in the fish gut as an indicator of environmental poisoning by methylamine. Proc. Acad. Environ. Biol., 6(1), 29-33.

[22] Tembhre, M., Ahirwar, S., Gour, S., \& Gaur, M. (2006). Chlorpyriphos induced inhibition of AChE in Cyprinus carpio and recovery during drug leaching. Journal of Cell and Tissue Research, 6(2), 793-796.

[23] Swamy, K. V., Ravikumar, R., \& Murali Mohan, P. (1992). Changes in cholinesterase system in different brain areas during the development of behavioral tolerance to monocrotophos toxicity in male albino rats. Biochemistry International, 27(4), 661- 669.

[24] Tembhre, M., Gour, G., Ahirwar, S. \& Namdeo, A. (2012). Diacetylemonoxime reactivation of Acetylecholinestrase and butyrylcholinesterase inhibited by dichlorovos in central and peripheral nervous system of Rat. IPCBB 48, IACIT press Singapore, 126-133. 
[25] Bartholomew, P. M., Glanutros, G., \& Cohen, S. (1985). Phosphalone-induced changes in regional cholinesterase activity. Toxicol. Apply. Pharmacol., 814, 147-155.

[26] Das, A., Shanker, G., Nath, C., Pal, R., Singh, S., \& Singh, H. K. (2002). A comparative study in rodents of standardized extracts of Bacopa monniera and Ginkgo Biloba. Pharmacology, Biochemistry and Behavior, 73, 893-900.

[27] Chandel, R. S., Kulshreshtha, D. K., \& Rastogi, R. P. (1977). Bacogenin, A3, a new sapoge-nin from Bacopa monniera. Phytochemistry, 16, 141-143.

[28] De Sarno, P., Pomponi, M., Giacobini, E., Tang, X. C., \& Williams, E. (1989). The effect of heptyl-physostigmine, a new cholinesterase inhibitor, on the central cholinergic system of the rat. Neurochemical Research, 14(10), 971-977.

[29] Liu, J., Zhang, H. Y., Wang, L. M., \& Tang, X. C. (1999). Inhibitory effects of huperzine B on cholinesterase activity in mice. Zhongguo Yao Li Xue Bao, 20(2), 141-145.

[30] Rao, G. V., \& Rao, K. S. (1995). Modulation in acetylcholinesterase of rat brain by pyrethroids in vivo and an in vitro kinetic study. Journal of Neurochemistry, 65, 2259-2266.

[31] Kadar, T., Shapira, S., Cohen, G., Sahar, R., Alkalay, D., \& Raveh, L. (1995). Sarin-induced neuropathology in rats. Hum. Exp. Toxicol., 14, 252-259.

[32] Le Mercier, G., Carpentier, P., Sentenac-Roumanou, H., \& Moralis, P. (1983). Histological and histochemical changes in the central nervous system of the rat poisoned by an irreversible anticholinesterase compound. Acta. Neuropathol., 61, 123-129.

[33] Carpentier, P., Lambrinidis, M., \& Blanchet, G., (1991). Early dendritic changes in hippocampus pyramidal neurons (field CA1) of rats subjected to acute soman intoxication; a light microscopic study, Brain Research, 541, 293-299.

[34] Zimmer, L. A., Ennis, M., \& Shipley, M. T. (1997). Soman-induced seizures rapidly activate astrocytes and microglia in discrete brain regions, J. Comp. Neurol., 378, 482-492.

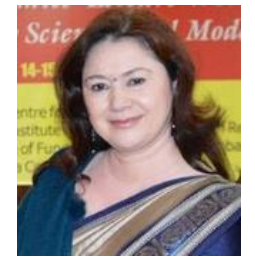

Manju Tembhre was born on August 31, 1960. She. is the Principal of M K Ponda College of Business and Management, Bhopal, Lambakheda, Berasia Road, Bhopal, India. She received her M.Sc., M.Phil, and Ph.D. (Zoology) from Barkatullah University, Bhopal, India. She has worked 8 years from 2006 continuing and taught 29 years in P.G. \& U.G. classes.

Her research fields are biotechnology \& zoology. And she has studied in the fields of neurotoxicology, enzyme kinetics, and histopathology, histo-chemistry \& environmental pollution for 22 years. She is the reviewer and author of Elsevier Editorial system - Journal of Pesticide, Biochemistry and Physiology published from The Netherlands. She is also a member of editorial board in (i) International Journal of Pharmacology and Biological Sciences. (ii) Asian Journal of Experimental Sciences - India. (iii) Electronic Journal of Environmental Sciences, CTR Publication. Publication of Book (1) Fish and Fisheries, (2) Anatomy and Physiology of Fishes.

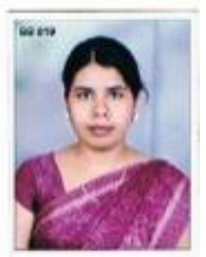

Shanta Ahirwar is presently working as an assistant professor of zoology in Government College, Bareli, Raisen, Bhopal (MP) India. She did her graduation and post-graduation from Sarojini Naidu Girls (Autonomous) Postgraduate College, Bhopal, (MP). She has done her PhD from Barkatullah University, Bhopal. Four research publications are to her credit. 
Sandhya Gour obtained M.Sc. and PhD in zoology from Barkatullah University. Presently she is working as an assistant professor in zoology in Govt. College at MP.

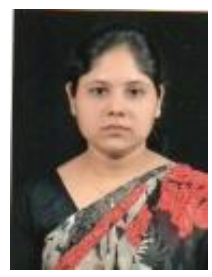

Anjali Namdeo obtained M.Sc. and PhD in zoology from Barkatullah University. Presently she is working as an assistant professor in zoology in Govt. College at MP. 